\title{
Tamaulipan thornscrub after fire: an analysis of the composition of species
}

\author{
E. Alanis-Rodríguez ${ }^{a}$ (D), E. A. Rubio-Camacho ${ }^{b}$ (D), J. M. Mata-Balderas ${ }^{a, c *}$ (D), \\ E. A. Lozano-Cavazos ${ }^{\text {(D), M. A. González-Tagle }}$ (D) and M. F. Amarán-Ruiz ${ }^{e}$ (D)
}

${ }^{a}$ Facultad de Ciencias Forestales, Universidad Autónoma de Nuevo León, Carretera Linares-Cd, Victoria Km 145, Linares, Nuevo León, México

'Instituto Nacional de Investigaciones Forestales, Agrícolas y Pecuarias - INIFAP, Centro de Investigación Regional Pacífico Centro - Campo Experimental, Centro Altos de Jalisco, Jalisco, México

'Gestión Estratégica y Manejo Ambiental S.C., Carretera San Miguel-Huinalá, 935, Segundo Piso, Local 30, Plaza Comercial Acanto, 66647, Apodaca, Nuevo León, México

${ }^{\mathrm{d}}$ Departamento de Recursos Naturales Renovables, Universidad Autónoma Agraria Antonio Narro, Calzada Antonio Narro, 1923, Buenavista, Saltillo, Coahuila, México

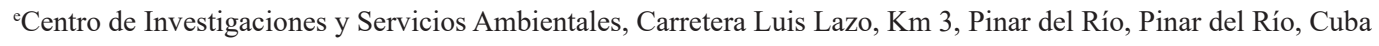

*e-mail: manuelmata792@gmail.com

Received: March 19, 2019 - Accepted: August 6, 2019 - Distributed: November 30, 2020

(With 3 figures)

\begin{abstract}
Forest fires are a natural element in many terrestrial ecosystems, in Mexico one of the main causes of loss of vegetation coverage is related to them. Nevertheless, no research has been carried out in the Tamaulipan thornscrub communities regarding post-fire regenerative strategies of plant species, therefore, is important to generate knowledge about the ecological role of fire in them. The aim of this study is to characterize the arboreal and shrub vegetation of a Tamaulipan thornscrub community in the Northeast of Mexico after a fire. To determine the composition, diversity and structure of the floral community consisting of trees and shrubs, 6 square-shaped sampling sites of 1,600 $\mathrm{m}^{2}$ were established 3 years after the fire. Margalef $\left(D_{M g}\right)$, Shannon-Weiner $\left(H^{\prime}\right)$ and Pretzsch $(A)$ indices were calculated to determine the richness, diversity and vertical stratification of species, respectively.23 species, 21 genera and 14 families of vascular plants were registered. The most species were Fabaceae (6) and Rhamnaceae (3) and Cordia boissieri was the specie with greater ecological weight $(\mathrm{IVI}=20.3 \%)$. The indexes of richness and true diversity $\left(D_{M g}=3.16 ; D=16.44\right)$ showed high values, which suggests that the post-fire area has a good regeneration and a high species diversity. With these results we can conclude that the fire is an important agent of change in successional stages of Tamaulipan thornscrub with high values of regeneration after a surface fire.
\end{abstract}

Keywords: diversity, fire ecology, forest fire, structure, vegetation regeneration.

\section{Espinho de Tamaulipan após incêndio: uma análise da composição das espécies}

\begin{abstract}
Resumo
Os incêndios florestais são um elemento natural em muitos ecossistemas terrestres, no México uma das principais causas de perda de cobertura vegetal está relacionada a eles, no entanto, nenhuma pesquisa foi realizada nas comunidades de espinheiros de Tamaulipan sobre as estratégias regenerativas pós-fogo de espécies de plantas, portanto, é importante gerar conhecimento sobre o papel ecológico do fogo neles. O objetivo deste estudo é caracterizar a vegetação arbórea e arbustiva de uma comunidade de plantas espinhosas no Tamaulipas, nordeste do México após um incêndio. Para determinar a composição, diversidade e estrutura da comunidade vegetal constituída por árvores e arbustos, seis locais de amostragem em forma de quadrado de $1.600 \mathrm{~m}^{2}$ cada um, foram estabelecidos três anos após o incêndio. Índices de Margalef (DMg), Shannon-Weiner (H') e Pretzsch (A) foram calculados para determinar a riqueza, diversidade e estratificação vertical das espécies, respectivamente. Foram registradas 23 espécies, 21 gêneros e 14 famílias de plantas vasculares. As mais ricas foram Fabaceae (6) e Rhamnaceae (3), Cordia boissieri foi a espécie com maior peso ecológico $(\mathrm{IVI}=20,3 \%)$. Os índices de riqueza e diversidade verdadeira $(\mathrm{DMg}=3,16 ; \mathrm{D}=16,44)$ apresentaram valores elevados, o que sugere que a área pós-fogo apresenta boa regeneração e alta diversidade Vegetal. Com estes resultados podemos concluir que o fogo é um importante agente de mudança nos estágios sucessionais do espinho de Tamaulipan com altos valores de regeneração após um incêndio na superfície.
\end{abstract}

Palavras-chave: diversidade, ecologia do fogo, incêndio florestal, estrutura, regeneração de vegetação. 


\section{Introduction}

The forest fires are a natural element in many terrestrial ecosystems and they directly influence on their structure, composition and ecological dynamics (Agee, 1993; Pyne et al., 1996; Iñiguez et al., 2008; Alanís-Rodríguez et al., 2012; Carrillo et al., 2012). After a forest fire has been extinguished, open spaces are generated by the elimination of vegetation cover, which enhances the germination and regrowth of pre-existing individuals or present species in the soil seed bank (Pausas, 2004; Calvo et al., 2008; Sang et al., 2008; Vidal and Reif, 2011; Massi et al., 2017).

In Mexico one of the main causes of loss of vegetation coverage is related to forest fires, mostly due to anthropogenic causes, approximately $90 \%$ of recorded fires (México, 2006; Rodríguez-Trejo, 2008). Its relevance is attributed to direct contributions to soil erosion (Alanís-Rodríguez et al., 2012) and to the modification of the community structure (González Tagle et al., 2016). Therefore, is important to generate knowledge about the ecological role of fire in terrestrial ecosystems, in order to contribute to development plans and programs of sustainable management, adapted to specific ecosystems (Rodríguez-Trejo et al., 2012).

Worldwide there are numerous investigations which evaluate the vegetation response to mainly anthropogenic fire (Lloret, 2004; Afif Khouri and Oliveira Prendes, 2006; Calvo et al., 2008; Iñiguez et al., 2008; Vidal and Reif, 2011; Dodonov et al., 2018). In Mexico the most evaluated ecosystems are the temperate ones (Jiménez Pérez and Alanís Rodríguez, 2011; Islas Madrid et al., 2018; Carrillo et al., 2012; Rodríguez-Trejo, 2012; Alanís, 2012). While in xerophilous scrubs, such as Tamaulipan thornscrub, no research has been carried out to evaluate the post-fire regenerative strategies of the different plant species that compose it (Alanís Rodríguez et al., 2015).

Tamaulipan thornscrub (MET) is an abundant ecosystem historically used by local people in northeastern Mexico, in activities such as logging and forage for cattle; it has high specific richness and density of shrubs and trees (Heiseke and Foroughbakhch, 1985; Alanís Rodríguez et al., 2008; Mora Donjuán et al., 2013).

Due to the lack of knowledge about the species fire ecology and the responses of MET to wildfires, it is important to study the fire effects over the MET regeneration and how is the resulting ecosystem in terms of forest structure and species composition. We believe that the regeneration of the vegetation after a wildfire can register high ecological values and similar records of species diversity and vertical distribution. Therefore, the aim of this study is to characterize the arboreal and shrub vegetation of Tamaulipan thornscrub in the Northeast of Mexico after a fire, through: 1) ecological parameters of abundance (ARi), dominance (DRi), frequency (FRi) and the importance values index (IVI); 2) species diversity indexes such as those of Shannon and Margalef, and $3)$ the vertical species distribution index $(A)$.

\section{Material and Methods}

\subsection{Study area}

The present research was carried out in a Community of the Tamaulipan thornscrub (MET) in the municipality of Montemorelos, Nuevo Leon (northeastern Mexico). The study area is located between the coordinates $25^{\circ} 2^{\prime}$ north latitude and $99^{\circ} 41^{\prime}$ west latitude (Figure 1), with an altitude of 410 m.a.s.1., with arid desert-hot climate

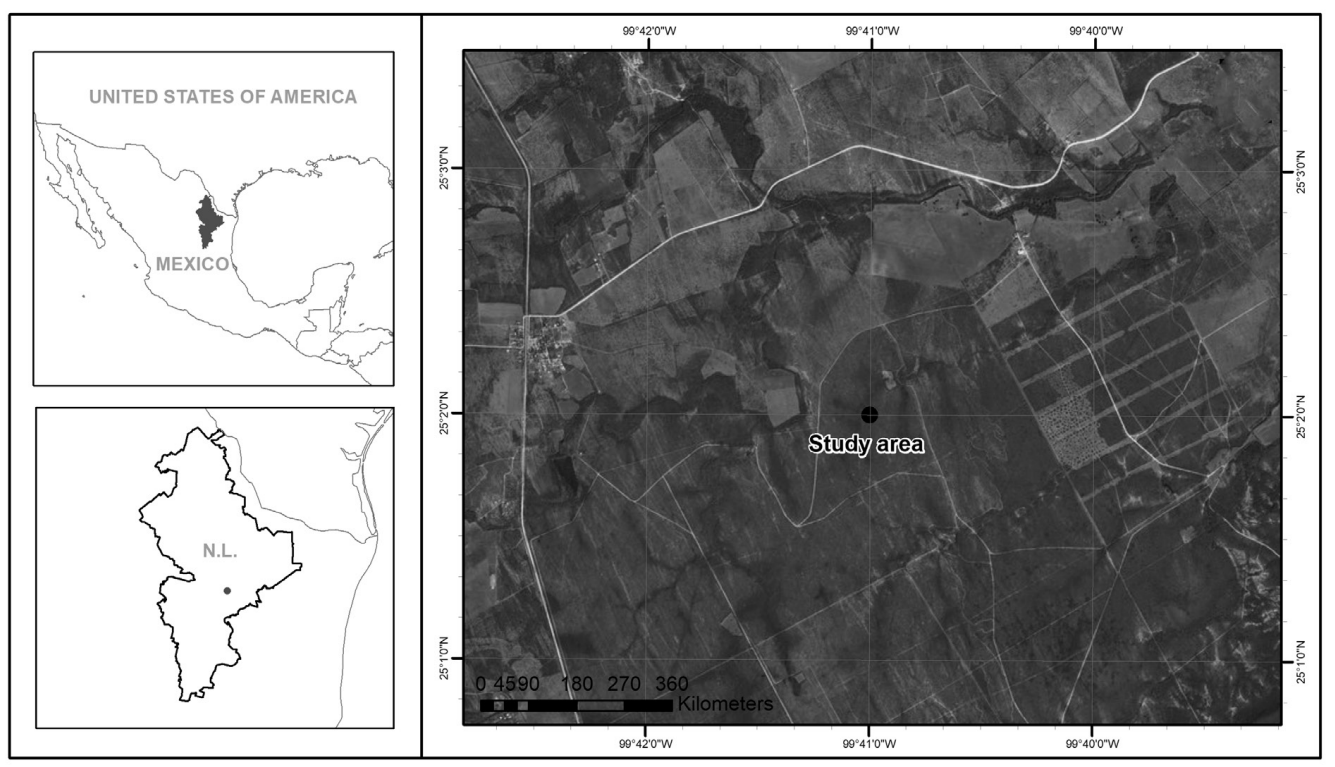

Figure 1. Upper left image outstands the location of Nuevo Leon in Mexico. Lower left image shows the location of the study area in the municipality of Montemorelos. Right image exposes the satellite image of the study area after a surface and crown mixed fire. 


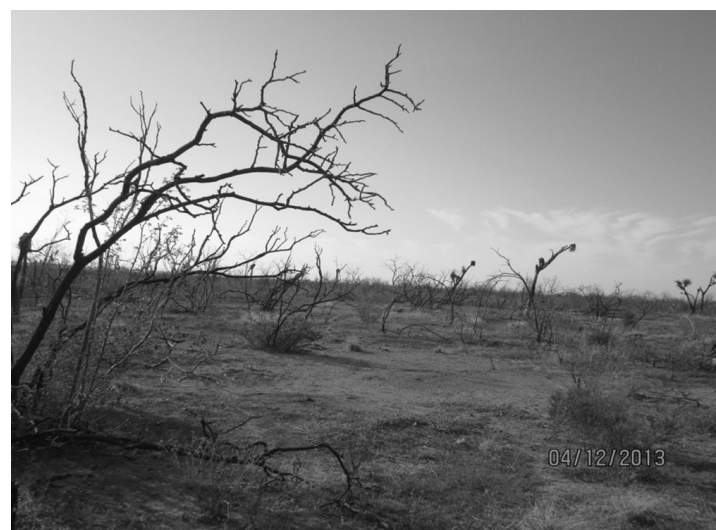

Figure 2. Photograph of the Tamaulipan thornscrub after fire in the study area.

(600 and $1000 \mathrm{~mm}$ of annual precipitation) with the highest incidence of rain in the month of September, and an annual average temperature of $18^{\circ} \mathrm{C}$. It belongs to the system of lower hills with soft slope, where the predominant soil types are the regosols.

In the summer of 2010 occurred a surface and crown mixed fire, affecting the vegetal elements. The fire extension was about 3,600 hectares and burned the aerial parts from most the trees and shrubs, with the exception of the Yucca filifera Chabaud species, due to its height, it did not suffer damage to the leaves, as observed in Figure 2.

\subsection{Vegetation analysis}

In April 2013, 6 square-shaped sampling sites of 1,600 $\mathrm{m}^{2}$ were established into a stand of Ejido "Las Huertas". At the sampling sites, the regeneration of shrubs and trees was evaluated 3 years after the fire occurred. The distribution of the sampling sites was at random scheme.

To obtain the minimum number of sampling sites, a species-area curve was elaborated (Mostacedo and Fredericksen, 2000). This was verified with a Bray-Curtis ordination model, a graphic representation of the variation in vegetal composition, known as one of the methods to evaluate beta-diversity. The model is based on an algorithm that permits to analyze the similarity of the sampling sites, calculating the percentage of similarity (0-100\%) in a distance unit (Beals, 1984), in this case it was developed using the program BioDiversity Pro 2.0 (McAleece et al., 1997).

At each sampling site a census of shrubs and trees was carried out, taking into consideration the basal diameter at ten centimeters of height $\left(d_{0.10}\right)$ and the number of sprouts presented by each individual, the crown diameter through a tape measure, measuring the occupied space in north-south and east-west directions and the total height. Moreover, a botanical identification of all evaluated species was performed in the herbarium of the Faculty of Forestry Sciences of the Autonomous University of Nuevo León.

\subsection{Data analysis}

The abundance of every species $\left(A_{i}\right)$ was determined, according to the number of trees per hectare, their dominance $\left(D_{i}\right)$, as a function of the crown area $(A C)$, and their frequency $\left(F_{i}\right)$ based on their presence in the sampling sites. The results were used to obtain a taxon-weighted value called Relative Importance Value Index (IVI), which acquires percentage values on a scale of 0 to 100 (Mostacedo and Fredericksen, 2000).

The formulas used for calculating the indices are described below.

Absolute $\left(A_{i}\right)$ and relative $\left(A R_{i}\right)$ abundances were evaluated using the following Formulas 1 and 2 :

$\mathrm{A}_{\mathrm{i}}=\mathrm{N}_{\mathrm{i}} \mathrm{S}$

$\mathrm{AR}_{\mathrm{i}}=\left(\mathrm{A}_{\mathrm{i}} \sum_{\mathrm{i}=1 \ldots \mathrm{n}} \mathrm{Ai}\right) 100$

where: $A_{i}=$ is the absolute abundance; $A R_{i}=$ is the relative abundance of species i relative to total abundance; $N_{i}=$ is the number of individuals of species I; $S=$ the sampling surface $\left(\mathrm{ha}^{-1}\right)$.

The absolute $\left(D_{i}\right)$ and relative $\left(D R_{i}\right)$ dominance was evaluated by the following Formulas 3 and 4:

$\mathrm{D}_{\mathrm{i}}=\mathrm{AC}_{\mathrm{i}} \mathrm{S}($ ha $)$

$\mathrm{DR}_{\mathrm{i}}=\left(\mathrm{D}_{\mathrm{i}} \sum_{\mathrm{i}=1 \ldots \mathrm{n}} \mathrm{Di}\right) * 100$

where: $D_{i}=$ is the absolute dominance; $D R_{i}=$ Is the relative dominance of species i with respect to total dominance; $A C=$ The crown area of species I; $S=$ the surface $\left(\mathrm{ha}^{-1}\right)$.

The absolute $\left(F_{i}\right)$ and relative $\left(F R_{i}\right)$ frequencies were obtained with the following Formulas 5 and 6 :

$\mathrm{F}_{\mathrm{i}}=\mathrm{P}_{\mathrm{i}} \mathrm{NS}$

$\mathrm{FR}_{\mathrm{i}}=\left(\mathrm{F}_{\mathrm{i}} \sum_{\mathrm{i}=1 \ldots \mathrm{n}} \mathrm{Fi}\right) * 100$

where: $F_{i}=$ is the absolute frequency; $F R_{i}=$ Is the relative frequency of species i with respect to the total frequency; $P_{i}=$ Is the number of sites where species $\mathrm{i}$ is present; $N S=$ The total number of sampling sites.

The importance value index (IVI) is defined by Moreno (2001), as shown in Equation 7:

$\mathrm{IVI}=\frac{\mathrm{AR}_{\mathrm{i}}+\mathrm{DR}_{\mathrm{i}}+\mathrm{FR}_{\mathrm{i}}}{3}$

To evaluate the diversity of regenerated species, the method proposed by Jost (2006), who recognizes "true diversity" using effective species numbers, is used as a modification to the Shannon entropy index. For this analysis the order $q=1$ was taken into account, where the proportional abundance of each species is considered (Jost, 2006). The Equation 8 is represented as:

${ }^{1} \mathrm{D}=\exp \left(-\sum_{\mathrm{i}=1}^{\mathrm{s}} \mathrm{p}_{\mathrm{i}}{ }^{*} \ln \mathrm{p}_{\mathrm{i}}\right)$ 
where: ${ }^{1} \mathrm{D}$ is true diversity, exp is the exponential, $\mathrm{S}$ represents the number of species present, In equals Natural logarithm of $p i$ which is the proportion of species, $p i=n i / N$, where $n i$ is the number of individuals of the species $i$ and $N$ is the total number of individuals.

To estimate species richness, the Margalef index $\left(D_{M g}\right)$ was used by equations (Magurran, 1989).

$$
\mathrm{D}_{\mathrm{Mg}}=\frac{(\mathrm{S}-1)}{\log \mathrm{N}}
$$

where: $\mathrm{S}$ is the number of species present, $\mathrm{N}$ is the total number of individuals and ni is the number of individuals of species $i$.

For the characterization of the vertical structure of the species, the Pretzsch index (A) was used (Pretzsch, 1996; Del Río et al., 2003). This index uses a vertical stratification of the forest in which the height of the forest is divided into three zones (Pretzsch, 1996; Jiménez et al., 2001); Zone I: $80-100 \%$ of the maximum height of the area; Zone II: $50-80 \%$, and zone III: 0 to $50 \%$. To define the zones the height of the individual is taken as high as $100 \%$ and from there the others are estimated. The $A$ index uses values between 0 and a maximum value $\left(A_{\max }\right)$; a value $A=0$ means that the stand consists of a single species occurring in a single stratum. $A_{\max }$ is reached when all species occur in the same proportion both in the stand and in the different strata (Pretzsch, 1996; Corral Rivas et al., 2005).

This index $(A)$ serves to determine the structural diversity in the vertical distribution of the species and is calculated with the following Formula 10:

$A=-\sum_{i=1}^{S} \sum_{j=1}^{Z} p_{i j} * \ln p_{i j}$ where: $S=$ Number of species present; $Z=$ Number of height stratas; $p_{\mathrm{ij}}=$ Percentage of species in each zone, and is estimated by the following Equation 11:

$\mathrm{p}_{\mathrm{ij}}=\mathrm{n}_{\mathrm{i}, \mathrm{j}} / \mathrm{N}$

where: $n_{i, j}=$ Number of individuals of the same species $(i)$ in zone $(j) ; N=$ Total number of individuals.

In order to compare the Pretzch index it is necessary to standardize it and this is done by the value of $A_{\max }$, which is calculated as shown in Equations 12 and 13:

$\mathrm{A}_{\max }=\ln \left(\mathrm{S}^{*} \mathrm{Z}\right)$

Then the value of $A$ can be standardized according to:

$\mathrm{A}_{\mathrm{rel}}=\frac{\mathrm{A}}{\ln (\mathrm{S} * \mathrm{Z})} * 100$

From the previous, it can be made comparisons between stands in which different species occur.

\section{Results}

\subsection{Floristic composition}

There were found 12 orders, 14 families, 21 genera and 23 species. The families Fabaceae and Rhamnaceae registered more species with 6 and 3 respectively, followed by the Euphorbiaceae and Rutaceae families with two species each; for the remaining families only one species was recorded (see Table 1). According to the Bray-Curtis ordination model, it was determined that the evaluated areas have an intermediate floristic similarity (Figure 3). In every comparison a similarity between $45.16 \%$ and

Table 1. List of species recorded in Tamaulipas thornscrub after fire.

\begin{tabular}{|c|c|c|}
\hline Scientific name & Family & Life form \\
\hline Gymnosperma glutinosum (Spreng.) Less & Asteraceae & Shrub \\
\hline Cordia boissieri A. DC. & Boraginaceae & Arboreal \\
\hline Parkinsonia aculeata $\mathrm{L}$. & Caesalpiniaceae & Arboreal \\
\hline Bernardia myricifolia (Scheele) Benth. \& Hook. & Euphorbiaceae & Shrub \\
\hline Croton suaveolens Torr. & Euphorbiaceae & Shrub \\
\hline Caesalpinia mexicana A. Gray & Fabaceae & Shrub \\
\hline Eysenhardtia polystachya (Ortega) Sarg. & Fabaceae & Shrub \\
\hline Havardia pallens (Benth.) Britton \& Rose & Fabaceae & Arboreal \\
\hline Prosopis laevigata (Humb. \& Bonpl. ex Willd.) M.C. Johnst. & Fabaceae & Arboreal \\
\hline Vachellia farnesiana (L.) Wight \& Arn. & Fabaceae & Shrub \\
\hline Vachellia rigidula (Benth.) Seigler \& Ebinger & Fabaceae & Shrub \\
\hline Yucca filifera (Chabaud, 1976) & Liliaceae & Arboreal \\
\hline Hibiscus cardiophyllus Gray. & Malvaceae & Shrub \\
\hline Forestiera angustifolia Torr. & Oleaceae & Shrub \\
\hline Condalia hookeri N.C.Johnst & Rhamnaceae & Arboreal \\
\hline Condalia lycioides (Gray) & Rhamnaceae & Shrub \\
\hline Karwinskia humboldtiana (R \& S) Succ. & Rhamnaceae & Shrub \\
\hline Helietta parvifolia (A.Gray ex Hemsl.) Benth. & Rutaceae & Shrub \\
\hline Zanthoxylum fagara (L.) Sarg. & Rutaceae & Shrub \\
\hline Sideroxylon celastrinum (Kunth) T.D. Penn. & Sapotaceae & Shrub \\
\hline Leucophyllum frutescens (Berland.) I.M. Johnst. & Scrophulariaceae & Shrub \\
\hline Celtis pallida Torr. & Ulmaceae & Shrub \\
\hline Lantana camara $\mathrm{L}$. & Verbenaceae & Shrub \\
\hline
\end{tabular}




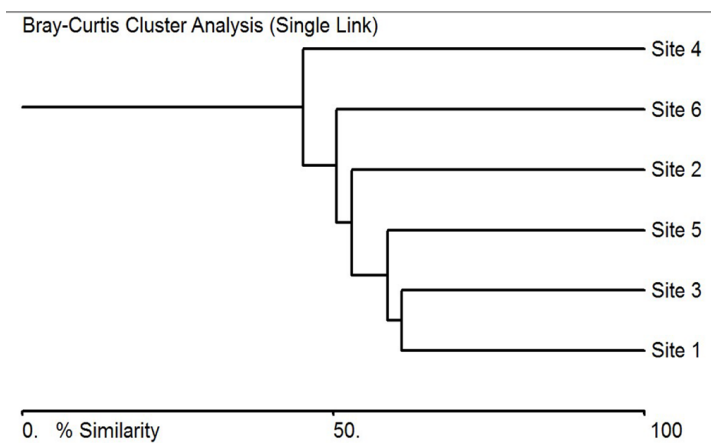

Figure 3. Floristic similarity between sites according to the Bray-Curtis ordination model.
$60.96 \%$ was observed. The species that were present in the six sampling sites were Cordia boissieri, Vachellia rigidula and Havardia pallens.

\subsection{Ecological parameters}

Abundance. For the number of individuals per hectare, three species were the most abundant. Cordia boissieri A.DC. was the most abundant species with 105 individuals per hectare $\left(\mathrm{N} \mathrm{ha}^{-1}\right)$, followed by the Vachellia rigidula (Benth.) Seigler \& Ebinger with $75 \mathrm{Nha}^{-1}$ and Leucophyllum frutescens (Berland.) I.M. Johnst. with $71.9 \mathrm{~N} \mathrm{ha}^{-1}$ (as shown in Table 2). These three species represents the $34.2 \%$ of the total abundance in the community.

Table 2. Abundance, dominance, frequency and index of importance value of the species of the post-fire Tamaulipas thornscrub.

\begin{tabular}{|c|c|c|c|c|c|c|c|}
\hline \multirow{3}{*}{ Specie } & \multicolumn{2}{|c|}{ Abundance } & \multicolumn{2}{|c|}{ Dominance } & \multicolumn{2}{|c|}{ Frequency } & \multirow{3}{*}{$\begin{array}{c}\text { Importance } \\
\text { Value Index } \\
\text { (IVI) }\end{array}$} \\
\hline & Abs & Rel & Abs & Rel & Abs & Rel & \\
\hline & $\mathbf{N} \mathbf{h a}^{-1}$ & $\%$ & $\mathbf{m}^{2} \mathbf{h a}^{-1}$ & $\%$ & N/ Site & $\%$ & \\
\hline Cordia boissieri & 105 & 14.2 & 236.5 & 39.3 & 6 & 7.5 & 20.3 \\
\hline Vachellia rigidula & 75 & 10.2 & 74.8 & 12.4 & 6 & 7.5 & 10.0 \\
\hline Havardia pallens & 63 & 8.5 & 63.8 & 10.6 & 6 & 7.5 & 8.9 \\
\hline Leucophyllum frutescens & 72 & 9.8 & 19.5 & 3.2 & 4 & 5.0 & 6.0 \\
\hline Croton suaveolens & 70 & 9.6 & 16.4 & 2.7 & 4 & 5.0 & 5.8 \\
\hline Eysenhardtia polystachya & 42 & 5.7 & 36.2 & 6.0 & 4 & 5.0 & 5.6 \\
\hline Gymnosperma glutinosum & 58 & 7.9 & 14.2 & 2.4 & 5 & 6.3 & 5.5 \\
\hline Karwinskia humboldtiana & 27 & 3.6 & 13.8 & 2.3 & 5 & 6.3 & 4.0 \\
\hline Condalia lycioides & 28 & 3.8 & 10.3 & 1.7 & 5 & 6.3 & 3.9 \\
\hline Celtis pallida & 17 & 2.3 & 24.3 & 4.0 & 4 & 5.0 & 3.8 \\
\hline Bernardia myricifolia & 26 & 3.5 & 7.3 & 1.2 & 5 & 6.3 & 3.7 \\
\hline Vachellia farnesiana & 16 & 2.1 & 19.4 & 3.2 & 3 & 3.8 & 3.0 \\
\hline Hibiscus cardiophyllus & 19 & 2.5 & 15.5 & 2.6 & 3 & 3.8 & 3.0 \\
\hline Zanthoxylum fagara & 22 & 3.0 & 7.7 & 1.3 & 3 & 3.8 & 2.7 \\
\hline Forestiera angustifolia & 20 & 2.8 & 8.3 & 1.4 & 3 & 3.8 & 2.6 \\
\hline Sideroxylon celastrinum & 14 & 1.9 & 7.5 & 1.2 & 3 & 3.8 & 2.3 \\
\hline Condalia hookeri & 20 & 2.8 & 4.8 & 0.8 & 2 & 2.5 & 2.0 \\
\hline Lantana camara & 8 & 1.1 & 7.2 & 1.2 & 2 & 2.5 & 1.6 \\
\hline Caesalpinia mexicana & 6 & 0.8 & 4.8 & 0.8 & 2 & 2.5 & 1.4 \\
\hline Helietta parvifolia & 13 & 1.7 & 5.9 & 1.0 & 1 & 1.3 & 1.3 \\
\hline Parkinsonia aculeata & 5 & 0.6 & 0.7 & 0.1 & 2 & 2.5 & 1.1 \\
\hline Prosopis laevigata & 9 & 1.3 & 3.3 & 0.5 & 1 & 1.3 & 1.0 \\
\hline Yucca filifera & 2 & 0.2 & 0.1 & 0.0 & 1 & 1.3 & 0.5 \\
\hline & 735 & 100 & 602.2 & 100 & 80 & 100 & 100 \\
\hline
\end{tabular}

Abs = Absolute values; Rel $=$ Relative values $(\%) ; \mathrm{N} \mathrm{ha}^{-1}=$ Number of trees per hectare; $\mathrm{N} /$ Site $=$ number of sampling sites in which the species is present. 
Dominance. Cordia boissieri is the most dominant species and covers $236.5 \mathrm{~m}^{2} \mathrm{ha}^{-1}$ which represent a $39.3 \%$ of the studied area. Vachellia rigidula with $74.8 \mathrm{~m}^{2} \mathrm{ha}^{-1}$ corresponded to $12.4 \%$ of the studied area, and Havardia pallens (Benth.) Britton \& Rose covered $63.8 \mathrm{~m}^{2} \mathrm{ha}^{-1}$ with a relative dominance of $10.6 \%$. It is important to highlight that the previous three species represented $62.3 \%$ of the total community coverage, while the remaining 20 species represent $37.7 \%$.

Frequency. The species with the highest frequency were Cordia boissieri, Havardia pallens and Vachellia rigidula with presence in all the sampling sites, corresponding to a $7.5 \%$ of the relative frequency. Bernardia myricifolia (Scheele) S. Watson, Condalia lycioides (A.Gray) Weberb., Gymnosperma glutinosum Less., and Karwinskia humboldtiana S. Watson were present in 5 out of 6 sites. The less frequent species were Helietta parvifolia (A.Gray ex Hemsl.) Benth., Prosopis leavigata (Humb. \& Bonpl. ex Willd.) M.C. Johnst., and Yucca filifera, with presence in only 1 of the 6 sampling sites (as shown in Table 2).

Importance value index (IVI). The greatest ecological value, obtained by the importance value index was $20.3 \%$ represented by $C$. boissieri species of IVIrel. The following species in terms of importance were $V$. rigidula with a $10 \%$ and $H$. pallens with $8.9 \%$. The previous three species together sum up $39.2 \%$ of IVIrel. The species with lower ecological value is the $Y$. filifera and P. leavigata with only $0.5 \%$ and $1 \%$, respectively of IVIrel (as shown in Table 2).

\subsection{Biological diversity}

According to the Margalef richness index $\left(D_{M g}\right)$, the evaluated area obtained 3.16 of $D_{M g}$. In relation to True Diversity index $\left({ }^{1} D\right)$, it showed a value of 16.44 .

\subsection{Vertical distribution of species $(A)$}

The analysis of the vertical distribution was made by defining three layers, high, medium and low. The upper layer is formed by Yucca filifera with 2 individuals per hectare $\left(\mathrm{N} \mathrm{ha}^{-1}\right)$ in this classification. The middle layer is formed by three species Eysenhardtia polystachya (Ortega) Sarg., Vachellia rigidula and Cordia boissieri with 2, 2 and $3 \mathrm{~N} \mathrm{ha}^{-1}$ respectively (as shown in Table 3). In the low layer, $99 \%$ of the individuals, including all species

Table 3. Values of species vertical distribution Pretzsch index (A) for Tamaulipan thornscrub community in study area.

\begin{tabular}{|c|c|c|c|c|}
\hline \multirow{3}{*}{ Stratum 1 (4.8 m) } & \multicolumn{4}{|c|}{ Pretzsch index (A) } \\
\hline & \multirow{2}{*}{$\mathbf{N}$} & \multirow{2}{*}{ N ha $\mathbf{h}^{-1}$} & \multicolumn{2}{|c|}{ Proportion (\%) } \\
\hline & & & From total & In the zone \\
\hline Yucca filifera & 1 & 2 & 100 & 0.002 \\
\hline Sum & 1 & 2 & 100 & 0.002 \\
\hline \multicolumn{5}{|l|}{ Stratum 2 (2.42 - $3.6 \mathrm{~m})$} \\
\hline Eysenhardtia polystachya & 1 & 2 & 25 & 0.002 \\
\hline Vachellia rigidula & 1 & 2 & 25 & 0.002 \\
\hline Cordia boissieri & 2 & 3 & 50 & 0.004 \\
\hline Sum & 4 & 6 & 100 & 0.008 \\
\hline \multicolumn{5}{|l|}{ Stratum $3(10 \mathrm{~cm}-2.23 \mathrm{~m})$} \\
\hline Bernardia myricifolia & 25 & 39 & 5 & 0.052 \\
\hline Caesalpinia mexicana & 4 & 6 & 1 & 0.008 \\
\hline Celtis pallida & 11 & 17 & 2 & 0.023 \\
\hline Condalia hookeri & 13 & 20 & 3 & 0.027 \\
\hline Condalia lycioides & 18 & 28 & 4 & 0.038 \\
\hline Cordia boissieri & 65 & 102 & 14 & 0.136 \\
\hline Croton suaveolens & 45 & 70 & 9 & 0.094 \\
\hline Eysenhardtia polystachya & 26 & 41 & 5 & 0.054 \\
\hline Forestiera angustifolia & 13 & 20 & 3 & 0.027 \\
\hline Gymnosperma glutinosum & 37 & 58 & 8 & 0.077 \\
\hline Havardia pallens & 40 & 63 & 8 & 0.084 \\
\hline Helietta parvifolia & 8 & 13 & 2 & 0.017 \\
\hline Hibiscus cardiophyllus & 12 & 19 & 3 & 0.025 \\
\hline Karwinskia humboldtiana & 17 & 27 & 4 & 0.035 \\
\hline Lantana camara & 5 & 8 & 1 & 0.010 \\
\hline Leucophillum frutescens & 46 & 72 & 10 & 0.096 \\
\hline Parkinsonia aculeata & 3 & 5 & 1 & 0.006 \\
\hline Prosopis laevigata & 6 & 9 & 1 & 0.013 \\
\hline Sideroxylon celastrinum & 9 & 14 & 2 & 0.019 \\
\hline Vachellia farnesiana & 10 & 16 & 2 & 0.021 \\
\hline Vachellia rigidula & 47 & 73 & 10 & 0.098 \\
\hline Zanthoxylum fagara & 14 & 22 & 3 & 0.029 \\
\hline Sum & 474 & 741 & 100 & 0.990 \\
\hline Total & 479 & 749 & 300 & 1.000 \\
\hline
\end{tabular}

$\mathrm{N}=$ Total number of individuals of the species in the stratum; $\mathrm{N} \mathrm{ha}^{-1}=$ Total number of individuals of the species per hectare in the stratum. 
of the studied area were registered wuth the exception of the Y. filifera. The most abundant species in the third layer were C. boissieri, V. rigidula, L. frutescens and Croton suaveolens Torr. with 102, 73, 72, and $70 \mathrm{~N} /$ ha-1, respectively (as shown in Table 3 ). The value of the A index was 2.84 with an Amax value of 4.23.

\section{Discussion}

In the present investigation, Fabaceae represented the highest number of species, similar to that reported by Alanís Rodríguez et al., (2008) and Jiménez Pérez et al. (2012) for the MET and by Gómez et al. (2009) and Hahn and Gómez (2008) in other shrublands, who stated that this family is the one with the highest number of species in these ecosystems. The 23 species recorded indicate a similarity in richness compared to mature MET communities, as reported by Mora Donjuán et al. (2013) and Marroquín-Castillo et al. (2016), who reported 21 and 23 species, respectively for MET reference areas. Of the aforementioned species, $V$. rigidula is the only species with the highest abundance in MET areas with different types of disturbances such as extensive cattle grazing and killing (Alanís Rodríguez et al., 2008). The highest values reported for this parameter in the MET in different areas with livestock and agricultural history are frequently supported by the species $V$. farnesiana and $V$. rigidula (Alanís Rodríguez et al., 2008; Pequeño Ledezma et al., 2012; Jiménez Pérez et al., 2012), being the latter one occuring in the burned area and with high values of importance (see Table 2). Different from Mora Donjuán et al. (2013) for an area with no recent disturbances, where the dominant species were Vachellia amentacea DC., Diospyros texana Scheele and C. boissieri, it is important to highlight that $C$. boissieri with the greatest dominance was present at the site of fire. On the other hand, the less dominant species belongs to the family Liliaceae represented by Yucca filifera, with $0.1 \mathrm{~m}^{2} \mathrm{ha}^{-1}$ of coverage, followed by Prosopis aculeata and P. laevigata with 0.7 and $3.3 \mathrm{~m}^{2} \mathrm{ha}^{-1}$ respectively (see Table 2). It is important to mention that the total covered area recorded was $602.2 \mathrm{~m}^{2} \mathrm{ha}^{-1}$, which represents an extremely low coverage, since $93.7 \%$ of the surface is found without vegetation due to the fire. The importance value index of the present study reports $C$. boissieri as the most important species (see Table 2), since in other MET study C. boissieri has not been reported with the highest importance value index (Alanis Rodríguez et al., 2008; Jiménez Pérez et al., 2012; Pequeño Ledezma et al., 2012; Mora Donjuán et al., 2013). The previous has great relevance, since it supposes that it is a pioneering post-fire species of the Tamaulipan thornscrub. Although there is no specific information on C. boissieri's regrowth capacity, it is documented that the genus Cordia has good resprouting capacity after fire (González Tagle, 2005; Alanís Rodríguez et al., 2011).

For the estimation of biodiversity, the Margalef index indicates a high species richness $\left(D_{M g} 3.16\right)$ when compared to other regenerated areas of the MET (Jiménez Pérez et al., 2012; Mora Donjuán et al., 2013) or studies in temperate forest ecosystems such as Alanís Rodríguez et al. (2010), with 1.59 and González Tagle (2005) with 1.5 as maximum values in this index. For the true diversity, which encompasses the abundance of species, it shows a value of 16.44. This means that the evaluated plant community has a diversity equal to that which would have a theoretically community of 16.44 species where all of them had the same abundance (Jost, 2006). Prezsch values indicate that the community evaluated had a high presence of individuals in the lower stratum (III) and a low presence in the rest of the heightzones. Based on the table of vertical strata and the results of Pretzsch index A, it was determined that the plant community is formed by a single cohort (III), where the individuals suffered the loss of the aerial part after the fire and are currently resprouting from the base. The remaining individuals in higher Cohorts I and II are those who survived the fire.

With our results we highlight the following: the studied community showed a specific richness of 23 species which is a high value when compared with other studies. The Cordia boissieri recorded a $20.3 \%$ of IVI being the species that showed a greater ecological weight in the study area. In addition, it is concluded that this species is pioneer associated with the fires in this area. The indexes of richness and true diversity $\left(D_{M g}=3.16 ;{ }^{1} D=16.44\right)$ showed high values, this suggests that the post-fire area has a good regeneration and a high species diversity. Regarding the species vertical distribution index in the burned area prevails the stratum III $(10 \mathrm{~cm}-2.23 \mathrm{~m})$, this indicates that the surface fire affected the aerial part of trees and shrubs and currently there is a dominant strata represented by individuals with regrowth.

\section{Acknowledgements}

To the Program of Improvement of the Teaching Staff (PROMEP) for the financing of the research through the project "Analysis of the natural regeneration of the tamaulipan thornscrub in northeastern Mexico".

\section{References}

AFIF KHOURI, E. and OLIVEIRA PRENDES, J., 2006. Efectos del fuego prescrito sobre matorral en las propiedades del suelo. Investigación Agraria: Sistemas y Recursos Forestales, vol. 15, no. 3, pp. 262-270.

AGEE, J.K., 1993. Fire ecology of Pacific Northwest forests. 2nd ed. Washington: Island Press, 477 p.

ALANÍS RODRÍGUEZ, E., ALANÍS RODRÍGUEZ, E., VALDECANTOS-DEMA, A., GONZÁLEZ-TAGLE, M.A., AGUIRRE-CALDERÓN, Ó.A. and TREVIÑO-GARZA, E.J., 2012. Composición y diversidad de la regeneración natural en comunidades de Pinus - Quercus sometidas a una alta recurrencia de incendios en el noreste de México. Revista Mexicana de Biodiversidad, vol. 83, no. 4, pp. 1207-1214. http://dx.doi. org/10.22201/ib.20078706e.2012.4.1013.

ALANÍS RODRÍGUEZ, E., JIMÉNEZ PÉREZ, J., AGUIRRE CALDERÓN, O.A., TREVIÑO GARZA, E.J., JURADO 
YBARRA, E. and GONZÁLEZ TAGLE, M.A., 2008. Efecto del uso del suelo en la fitodiversidad del matorral espinoso tamaulipeco. Ciencia UANL, vol. 11, no. 1, pp. 56-62.

\section{ALANÍS RODRÍGUEZ, E., JIMÉNEZ PÉREZ, J., CANIZALES} VELÁZQUEZ, P.A., GONZÁLEZ RODRÍGUEZ, H. and MORA-OLIVO, A., 2015. Estado actual del conocimiento de la estructura arbórea y arbustiva del matorral espinoso tamaulipeco del noreste de México. Revista Iberoamericana de Ciencias, vol. 2, no. 7, pp. 69-80.

ALANÍS, E., 2012. Regeneración natural y restauración ecológica post-incendio de un bosque mixto en el Parque Ecológico Chipinque, México. Ecosistemas, vol. 21, no. 1-2, pp. 206-210.

ALANÍS-RODRÍGUEZ, E., JIMÉNEZ-PÉREZ, J., PANDOMORENO, M., AGUIRRE-CALDERÓN, O.A., TREVIÑOGARZA, E.J. and CANIZALES-VELÁZQUEZ, P.A., 2010. Análisis de la diversidad arbórea en áreas restauradas post-incendio en el Parque Ecológico Chipinque, México. Acta Biologica Colombiana, vol. 15 , no. 2, pp. 309-324.

ALANÍS-RODRÍGUEZ, E., JIMÉNEZ-PÉREZ, J., VALDECANTOS-DEMA, A., PANDO-MORENO, M., AGUIRRE-CALDERÓN, O.A. and TREVIÑO-GARZA, E.J., 2011. Caracterización de regeneración leñosa post-incendio de un ecosistema templado del parque ecológico Chipinque, México. Revista Chapingo Serie Ciencias Forestales y del Ambiente, vol. 17, no. 1, pp. 31-39. http://dx.doi.org/10.5154/r.rchscfa.2010.05.032.

BEALS, E.W., 1984. Bray-Curtis ordination: an effective strategy for analysis of multivariate ecological data. Advances in Ecological Research, vol. 14, pp. 1-55. http://dx.doi.org/10.1016/ S0065-2504(08)60168-3.

CALVO, L., SANTALLA, S., VALBUENA, L., MARCOS, E., TÁRREGA, R. and LUIS-CALABUIG, E., 2008. Post-fire natural regeneration of a Pinus pinaster forest in NW Spain. Plant Ecology, vol. 197, no. 1, pp. 81-90. http://dx.doi.org/10.1007/ s11258-007-9362-1.

CARRILlO, L., RODRÍGUEZ, D., TCHIKOUÉ, H., MONTERROSO, A. and SANTILLAN, J., 2012. Análisis espacial de peligro de incendios forestales en Puebla, México. Interciencia, vol. 37, no. 9, pp. 678-683.

CORRAL RIVAS, J.J., A GUIRRE CALDERÓN, O.A., JIMÉNEZ PÉREZ, J. and CORRAL RIVAS, S., 2005. Un análisis del efecto del aprovechamiento forestal sobre la diversidad estructural en el Bosque Mesófilo de Montaña "El Cielo", Tamaulipas, México. Investigación Agraria: Sistemas y Recursos Forestales, vol. 14, no. 2 , pp. $217-228$.

DEL RÍO, M., MONTES, F., CAÑELLAS, I. and MONTERO, G., 2003. Índices de diversidad estructural en masas forestales. Investigación Agraria: Sistemas y Recursos Forestales, vol. 12, no. 1 , pp. 159-176.

DODONOV, P., ZANELLI, C.B. and SILVA-MATOS, D.M., 2018. Effects of an accidental dry-season fire on the reproductive phenology of two Neotropical savanna shrubs. Brazilian Journal of Botany, vol. 78, no. 3, pp. 564-573. http://dx.doi.org/10.1590/15196984.174660. PMid:29091119.

GÓMEZ, P., HAHN, S. and SAN MARTÍN, J., 2009. Estructura y composición florística de un matorral bajo plantaciones de Pinus radiata D.Don en Chile Central. Gayana. Botánica, vol. 66, no. 2, pp. 256-268. http://dx.doi.org/10.4067/S0717-66432009000200010.

GONZÁLEZ TAGLE, M.A., 2005. Fire history and natural succession after forest fires in pine-oak forests: an investigation in the ecological park "Chipinque”, northeast México. Göttingen: Fakultät für Forstwissenschaften und Waldökologie der GeorgAugust-Universität Göttingen, 161 p. Dissertation zur Erlangung des Doctorgrades.

GONZÁLEZ TAGLE, M.A., SCHWENDENMANN, L., JIMÉNEZ PÉREZ, J. and HIMMELSBACH, W., 2016. Reconstrucción del historial de incendios y estructura forestal en bosques mixtos de pino-encino en la Sierra Madre Oriental. Madera y Bosques, vol. 13, no. 2, pp. 51-63. http://dx.doi. org/10.21829/myb.2007.1321228.

HAHN, S. and GÓMEZ, P., 2008. Hallazgo de Adesmia Bijuga phil. (Fabaceae) en la zona costera, región del Maule, Chile Central. Gayana: Botánica, vol. 65, no. 1, pp. 119-121. http:// dx.doi.org/10.4067/S0717-66432008000100013.

HEISEKE, D. and FOROUGHBAKHCH, R., 1985. El matorral como recurso forestal. Linares: Facultad de Ciencias Forestales. U.A.N.L., 31 p. Reporte Científico, no. 1.

IÑIGUEZ, J.M., SWETNAM, T. and YOOL, S., 2008. Topography affected landscape fire history patterns in southern Arizona, USA. Forest Ecology and Management, vol. 256, no. 3, pp. 295-303. http://dx.doi.org/10.1016/j.foreco.2008.04.023.

ISLAS MADRID, G.E., RODRÍGUEZ TREJO, D.A. and MARTÍNEZ HERNÁNDEZ, P.A., 2018. Diversidad del sotobosque y radiación solar en un bosque de Pinus hartwegii lindl. con quema prescrita. Revista Mexicana de Ciencias Forestales, vol. 4, no. 15, pp. 25-40. http://dx.doi.org/10.29298/rmcf.v4i15.446.

JIMÉNEZ PÉREZ, J. and ALANÍS RODRÍGUEZ, E., 2011. Análisis de la frecuencia de los incendios forestales en la Sierra Madre Oriental y Occidental del norte de México y sur de Estados Unidos de América. Ciencia UANL, vol. 14, no. 3, pp. 255-263.

JIMÉNEZ PÉREZ, J., ALANÍS RODRÍGUEZ, E., RUIZ GONZÁLEZ, J.L, GONZÁLEZ TAGLE M.A., YERENA YAMALLEL, J.I. and ALANÍS FLORES, G., 2012. Diversidad de la regeneración leñosa del matorral espinoso tamaulipeco con historial agrícola en el noreste de México. Ciencia UANL, vol. 15 , no. 58 , pp. $66-71$.

JIMÉNEZ, J., AGUIRRE, O.A. and KRAMER, H., 2001. Análisis de la estructura horizontal y vertical en un ecosistema multicohortal de pino-encino en el norte de México. Investigación Agraria:Sistemas y Recursos Forestales, vol. 10, no. 2, pp. 355-366.

JOST, L., 2006. Entropy and diversity. Oikos, vol. 113, no. 2, pp. 363-375. http://dx.doi.org/10.1111/j.2006.0030-1299.14714.x.

LLORET, F., 2004. Régimen de incendios y regeneración. In: F. VALLADARES, ed. Ecología del bosque mediterráneo en un mundo cambiante. Madrid: Ministerio de Medio Ambiente, pp. 101-126

MAGURRAN, A., 1989. Diversidad ecológica y su medición. 1st ed. Barcelona: Ediciones Vedrá, pp. 101-126.

MARROQUÍN-CASTILLO, J.J., ALANÍS-RODRÍGUEZ, E., JIMÉNEZ-PÉREZ, J., AGUIRRE-CALDERÓN, O.A., MATA-BALDERAS, J.M. and CHÁVEZ-COSTA, A.C., 2016. Composición florística y diversidad de un área restaurada post-minería en el matorral espinoso tamaulipeco. Polibotánica, vol. 42, pp. 1-17. http://dx.doi.org/10.18387/polibotanica.42.1.

MASSI, K.G., EUGÊNIO, C.U.O. and FRANCO, A.C., 2017. Post-fire reproduction of herbs at a savanna-gallery forest boundary in Distrito Federal, Brazil. Brazilian Journal of Botany, vol. 77, no. 4, pp. 876-886. http://dx.doi.org/10.1590/1519-6984.06416. PMid:28492804. 
MCALEECE, N., LAMBSHEAD, P., PATERSON, G. and CAGE, J., 1997 [viewed 28 June 2019]. Biodiversity professional (V.2.0) [online]. Oban: Natural History Museum, Scottish Association for Marine Science. Available from: http://www.sams.ac.uk/research/ software/software/?searchterm=Biodiversity\%20Pro

MÉXICO. Secretaría de Medio Ambiente y Recursos Naturales - SEMARNAT, 2006 [viewed 22 November 2018]. El medio ambiente en México 2005: en resumen, 2006 [online]. México. Available from: http://www.semarnat.gob.mx

MORA DONJUÁN, C.A., ALANÍS RODRÍGUEZ, E., JIMÉNEZ PÉREZ, J., GONZÁLEZ TAGLE, M.A., YERENA YAMALLEL, I.J. and CUELLAR RODRÍGUEZ, L.G., 2013. Estructura, composición florística y diversidad del matorral espinoso tamaulipeco, México. Ecología Aplicada, vol. 12, no. 1-2, pp. 29-34. http://dx.doi.org/10.21704/rea.v12i1-2.435.

MORENO, C.E., 2001. Métodos para medir la biodiversidad. 1st ed. Zaragoza: CYTED, ORCYT-UNESCO y SEA, 83 p. Manual y tesis SEA, vol. 1.

MOSTACEDO, B. and FREDERICKSEN, T.S., 2000. Manual de métodos básicos de muestreo y análisis en ecología vegetal. Santa Cruz: El País, 87 p.

PAUSAS, J.G., 2004. La recurrencia de incendios en el monte mediterráneo. In: V.R. VALLEJO and J.A. ALLOZA, eds. Avances en el estudio de la gestión del monte Mediterráneo. Valencia: Fundación Centro de Estudios Ambientales del Mediterráneo, pp. 47-64.

PEQUEÑO-LEDEZMA, M.Á., ALANÍS-RODRÍGUEZ, E., JIMÉNEZ-PÉREZ, J., GONZÁLEZ-TAGLE, M.A., YERENA-YAMALLEL, I., CUELLAR-RODRÍGUEZ, G. and MORA-OLIVO,A., 2012. Análisis de la restauración pasiva post-pecuaria en el matorral espinoso tamaulipeco del noreste de México. CienciaUAT, vol. 7, no. 1, pp. 48-53. http://dx.doi. org/10.29059/cienciauat.v7i1.39.

PRETZSCH, H., 1996. Strukturvielfalt als Ergebnis waldbaulichen Handels. In: DEUTSCHER VERBAND FORSTLICHER, ed. Ertragskunde. Nehresheim: Sekt, pp. 134-154.

PYNE, S.J., ANDREWS, P.L. and LAVEN, R.D., 1996. Introduction to wildland fire. 2nd ed. New York: John Wiley \& Sons, 769 p.

RODRÍGUEZ-TREJO, D.A., 2008. Fire regimes, fire ecology, and fire management in Mexico. Ambio, vol. 37, no. 7-8, pp. 548-556. http://dx.doi.org/10.1579/0044-7447-37.7.548. PMid:19205177.

RODRÍGUEZ-TREJO, D.A., 2012. Génesis de los incendios forestales. Revista Chapingo Serie Ciencias Forestales y del Ambiente, vol. 18, no. 3, pp. 357-374. http://dx.doi.org/10.5154/r. rchscfa.2011.12.091.

RODRÍGUEZ-TREJO, D.A., MARTÍNEZ, A., MENDOZA BAUTISTA, C., GARCÍA, F., HERRERA, C. and DE JESÚS, A.F., 2012. Micro sites and seedling quality in restoration. Acta Botanica Gallica: Botany Letters, vol. 159, no. 3, pp. 299-301. http://dx.doi.org/10.1080/12538078.2012.737153.

SANG, W., CHEN, S. and LI, G., 2008. Dynamics of leaf area index and canopy openness of three forest types in a warm temperate zone. Frontiers of Forestry in China, vol. 3, no. 4, pp. 416-421. http://dx.doi.org/10.1007/s11461-008-0062-3.

VIDAL, O.J. and REIF, A., 2011. Effect of a tourist-ignited wildfire on Nothofagus pumilio forests at Torres del Paine biosphere reserve, Chile (Southern Patagonia). Bosques, vol. 32, no. 1, pp. 64-76. http://dx.doi.org/10.4067/S0717-92002011000100008. 